\title{
Methodological Approaches to Financing Higher Education Institutions in the Context of Digitalizing the Russian Higher Education
}

\author{
Abordagens metodológicas para o financiamento de instituições de \\ ensino superior no contexto da digitalização do ensino superior russo
}

\section{Enfoques metodológicos para financiar instituciones de educación superior en el contexto de la digitalización de la educación superior rusa}

\author{
Vladimir Alexandrovich Slepov ${ }^{1}$ (D) Tatyana Nikolaevna Rodenkova ${ }^{1}$ (D), \\ Elena Ivanovna Gromova ${ }^{1}$ (D) Dmitry Alexandrovich Pokamestov ${ }^{1}$
}

${ }^{1}$ Plekhanov Russian University of Economics, Moscow, Russian Federation.

Corresponding author:

Vladimir Alexandrovich Slepov

Email: slepov.v.a@mail.ru

How to cite: Slepov, V. A., Rodenkova, A. N., Gromova, E. I., \& Pokamestov, D. A. (2021). Methodological Approaches to Financing Higher Education Institutions in the Context of Digitalizing the Russian Higher Education. Revista Tempos e Espaços em Educação, 14(33), e15928. http://dx.doi.org/10.20952/revtee.v14i33.15928

\begin{abstract}
Forecasting changes in the external and internal parameters of the socio-economic development of higher education (HE) as an integral system, as well as the risks of its digitalization that reduce the quality of human capital suggest the expansion of contemporary methodological instruments for financing higher education institutions (HEIs). In the article the principles of project financing that combine system and process approaches have been suggested, and the need to introduce the axiological approach into the methodological basis of project financing of HE as a specific way of organizing and performing financial activities, obtaining and using its results with regard to certain values, and neutralizing the risks of digitalizing education along with improving the quality of human capital has been substantiated.

Keywords: Methodological approaches. Principles of project financing of HEls. Index of the investment attractiveness of a HEl. Risks of implementing the Education national project. An axiological approach to project financing of HEls.
\end{abstract}

\section{RESUMO}

A previsão de mudanças nos parâmetros externos e internos do desenvolvimento socioeconômico do ensino superior (ES) como sistema integral, bem como os riscos de sua digitalização que reduzem a qualidade do capital humano, sugerem a expansão de instrumentos metodológicos contemporâneos de financiamento superior. instituições de ensino (IES). No artigo, os princípios do 
project finance que combinam abordagens de sistema e processo foram sugeridos, e a necessidade de introduzir a abordagem axiológica na base metodológica do project finance de ES como uma forma específica de organizar e executar atividades financeiras, obtendo e utilizando seus resultados no que diz respeito a determinados valores, e neutralizar os riscos da digitalização da educação, juntamente com a melhoria da qualidade do capital humano foram comprovados.

Palavras-chave: Abordagens metodológicas. Princípios de financiamento de projetos de IES. Índice de atratividade de investimento de uma IES. Riscos da implementação do projeto nacional de Educação. Uma abordagem axiológica para o financiamento de projetos de IES.

\section{RESUMEN}

Pronosticar cambios en los parámetros externos e internos del desarrollo socioeconómico de la educación superior (ES) como sistema integral, así como los riesgos de su digitalización que reducen la calidad del capital humano sugieren la expansión de instrumentos metodológicos contemporáneos para el financiamiento superior. instituciones educativas (IES). En el artículo se sugieren los principios del financiamiento de proyectos que combinan enfoques de sistemas y procesos, y la necesidad de introducir el enfoque axiológico en la base metodológica del financiamiento de proyectos de la ES como una forma específica de organizar y realizar actividades financieras, obteniendo y utilizando sus Se han corroborado resultados con respecto a determinados valores, y se ha comprobado la neutralización de los riesgos de digitalizar la educación junto con la mejora de la calidad del capital humano.

Palabras clave: Enfoques metodológicos. Principios de la financiación de proyectos de las IES. Índice del atractivo inversor de una IES. Riesgos de implementar el proyecto nacional de Educación. Un enfoque axiológico del financiamiento de proyectos de las IES.

\section{INTRODUCTION}

In a highly competitive educational system, the growth of human capital rather than the provision of financial resources becomes an essentially important source for the HEls' development, along with structural changes in the HE system and the implementation of national projects. The HE growth potential is formed by the intellectual and creative potential of HEls, i.e., qualified and creative employees integrated into the high-quality information and educational environment characterized by a high organizational culture and sufficient resource provision (Agasisti et al., 2019).

In their studies Ramos-Vielba (2016) and Coviello (2018) consider a HEI as a subject of management in the HE system, on the one hand, and as a relatively closed autopoiesis system, on the other hand. It is possible to identify key methodological approaches to financing HEls in the context of digitalization. At the same time, according to Ben-Ner (2017), these are the system, process, program-target, and project approaches. The system approach to financing HEls suggests managing financial flows of subjects and objects in the $\mathrm{HE}$ area that have certain relations with one another and with the other systems. The process approach allows decomposing the transformation of financial resources in the results of scientific and educational activities into two interrelated subprocesses: investments in the human capital development and investments in the development of the HEl's information and educational environment (Koh et al., 2014). Thus, the program-target and project approaches make it possible to improve the efficiency and performance of HEls' financing, and only the value-based approach combines all four approaches, minimizes the risks of digitalizing education, and improves in the quality of human capital. 


\section{MATERIALS AND METHODS}

Conceptually the study is based on the theory of budgeting developed by such economists as R. Brailey, B. Colass, S. Myers, and R. Anthony. According to Abramo (2013), this theory made it possible to form a new system of program-target management of the HE finances. At the same time, in terms of expanding theoretical approaches to financing educational institutions, according to Crespi (2008), they are considered in the studies of J. Mincer, T. Schultz, and G. Becker on the theory of human capital as the achievement of professional education. Methodologically the study is based on using the dialectical methods of cognition, such as the methods of analyzing knowledge systems, the axiomatic and inductive and deductive methods, as well as the methods of abstracting and concretizing information. They made it possible to formulate the axiological approach to project financing of HEls (Kumar et al., 2013).

Fundamental provisions of monographs and scientific articles devoted to the problems of financing and digitalizing the $\mathrm{HE}$, official data of passports of national projects, the Federal State Statistics Service of the Russian Federation, the Ministry of Science and Higher Education of the Russian Federation, and the Ministry of Economic Development of the Russian Federation were used as information and analytical materials of the study.

\section{RESULTS AND DISCUSSION}

The need to increase investments for digitalizing the HE is substantiated by the strategic objectives of the country's socio-economic development specified in the Education national project. They aim at creating "conditions for the formation of a knowledge society in the Russian Federation" (approved in 2017). In order to do this, it is necessary to optimally combine the methodology of state financing of HEls and the methodology of investing in the development of their scientific and educational potential based on project financing.

Along with this, the optimal combination of these approaches suggests the fulfillment of the reproductive function by state finances in $\mathrm{HE}$ in order to fulfill social obligations, on the one hand, and the stimulation of its development by focusing financial resources on the main points of growth and solving top priority tasks, on the other hand.

The relevance of project financing of education is determined by the fact that today, more than ever, the HE system should be considered as the investment area determining the country's economic growth rather than the cost-intensive one (Education, the current national project approved in 2017).

The authors believe that project financing of the HE development is a financial process that includes coordinated activities of the bodies governing and financing education aimed at achieving goals of the comprehensive and efficient functioning and development of HE implemented within a certain project (program) (Kosov et al., 2018).

Based on this, HE project financing should comply with the following principles:

- Purposefulness that supposes to specify goals of financing and investments in HE whose achievement is determined by the system of quantitative and qualitative indicators,

- Identification of participants defining objects and subjects of the financial support and investments, areas of their financial responsibility, and sanctions for failure to fulfill their obligations,

- Stability of financial relations when the volumes of financial resources approved for the whole period of the project (program) cannot be changed downward,

- Diversified (or multichannel) financing including both budgetary and nonbudgetary funding sources, as well as possible investment resources, 
- Priority, i.e., the focus of financial resources on achieving the goals and objectives determined by the relevant decrees of the President of the Russian Federation, national projects, federal programs, and decisions of educational authorities,

- Performance of investments in scientific and educational activities of HEls and human development, and

- Optimal distribution of risks among investors in research activities and educational innovations of HEls (Fig. 1).

Figure (1): Methodological Basis for the HE Financing

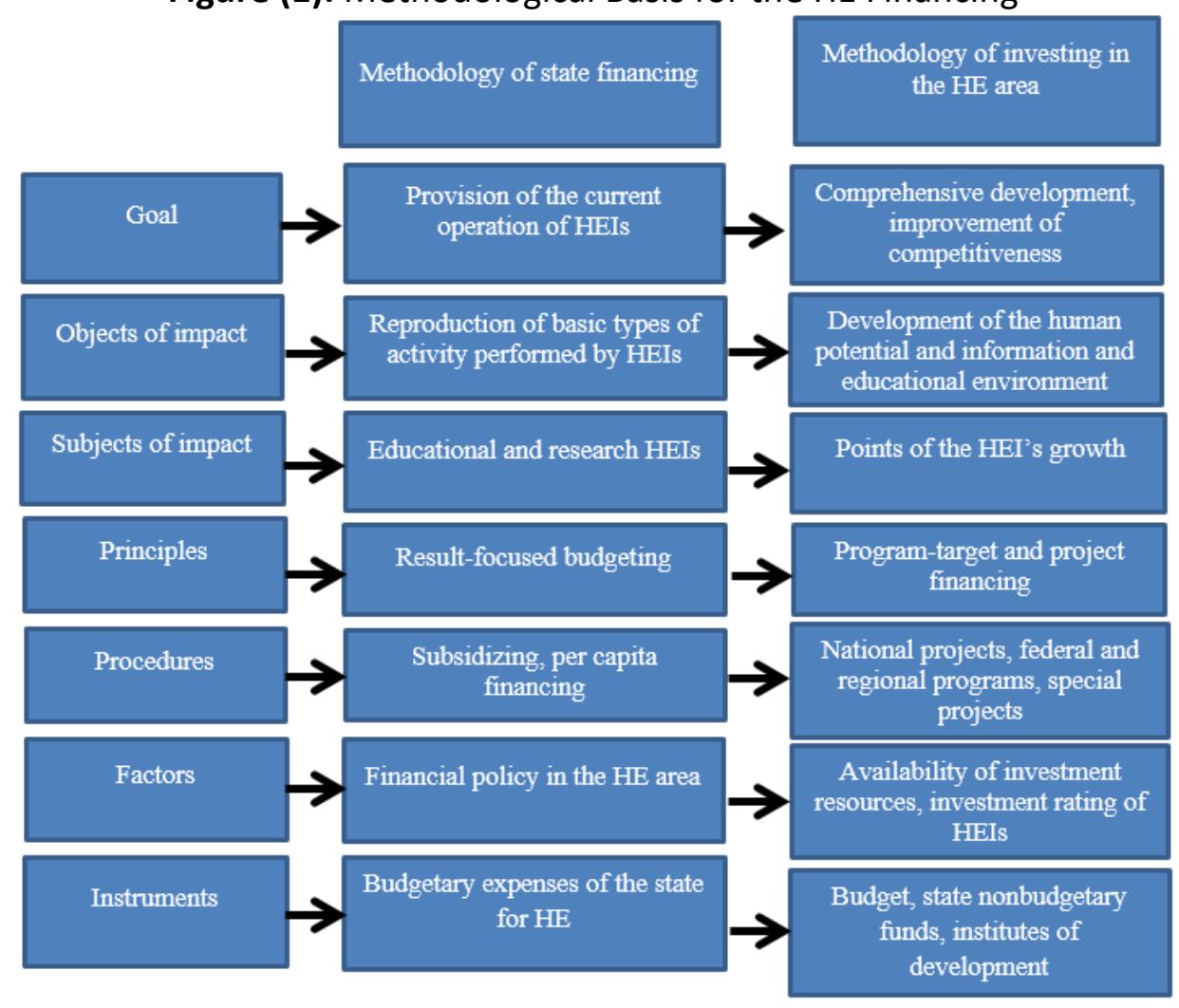

Today, the principle of purposeful financing and investment in the HE sector is implemented within national projects, e.g., Education, Science, Digital Economy, federal programs included in them, and the Development of Education state program. For example, the system of quantitative and qualitative indicators of the Education national project reflects the main results of four "key areas of the Russian education development: updating the content, creating the required modern infrastructure, training personnel to work in the system, their retraining and advanced training, as well as creating the most efficient sector management mechanisms". Indicators of the Science national project include a number of world-class scientific and educational centers. The system of indicators of the Digital Economy national project reflects the implementation of the Strategy for the Development of the Information Society in the Russian Federation for 2017 - 2030: "development of the human potential; formation of the information space, taking into account the needs of citizens and society in obtaining high-quality and reliable information; using and developing various educational technologies, including distance learning, e-learning, etc." (Sabharwal, 2013).

The principle of identifying participants that determines objects and subjects of the financial support and investments is important for managing financial flows in HE. The processes of financial support for the Russian HE "are characterized by polystructurality, hierarchical management, and the dominance of state organizations in the formation and distribution of financial resources" (Rodenkova, 2011). The objects of financing in HE include government authorities, relevant 
ministries, financing and regulating agencies, nonbudgetary funds, development institutions and public organizations, as well as corporate and private investors. The subjects include HEls of various types and organizational and legal forms, scientific and educational centers and clusters, research institutes, and other similar organizations that obtain financial resources, as well as educators and students (Fig. 2).

Figure (2): Interaction of HE Objects and Subjects in the Course of Financing

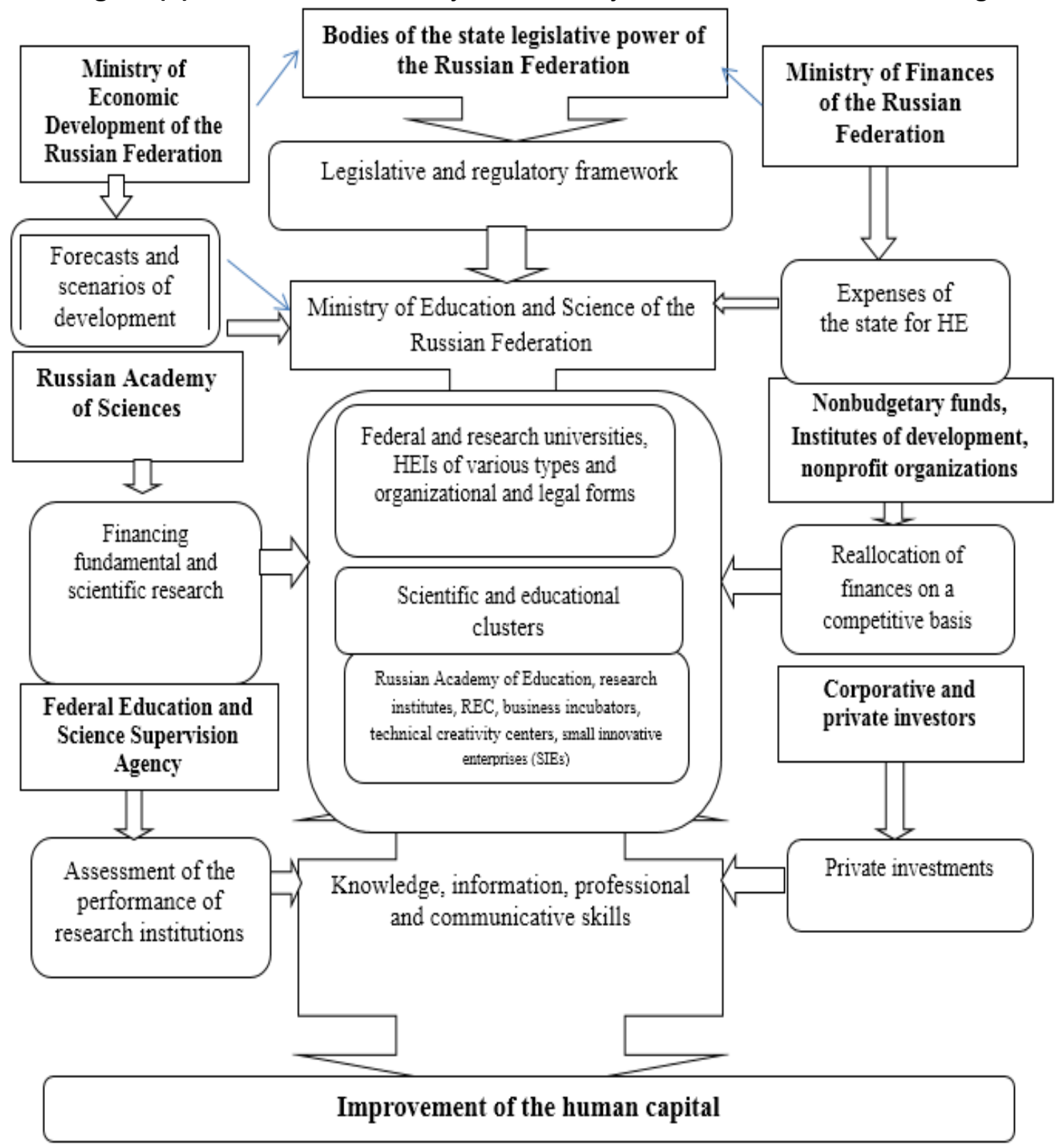

The principle of the stability of financial relations assumes a certain level of sufficiency of financial resources both for fulfilling social obligations (the availability of high-quality education) and for achieving the tasks set in national projects and federal and state programs for the development of education.

However, financial support of the Russian education is characterized by almost twenty years' underfunding in relation to the declared obligations in the development programs. "Russia where the compulsory education is as long as in developed countries and that is the world leader in vocational education coverage spends on education one and a half times less share of "public" funds than the main group of such countries $-3.5 \%$ of GDP against $5.2 \%$ of GDP" (the data from the Center of Strategic Developments and the Higher School of Economics, 
https://www.csr.ru/wpcontent/uploads). In the near future the trend is going to be the same (Table 1).

Table (1): Expenses of the Russian Federal Budget for Education in $2019-2022$

\begin{tabular}{|l|l|l|l|l|}
\hline & 2019 & 2020 & 2021 & 2022 \\
\hline GDP, RUB bln & 108,414 & 112,863 & 120,364 & 128,508 \\
\hline $\begin{array}{l}\text { Education, in total } \\
\text { (in \% as to GDP) }\end{array}$ & 0.8 & 0.8 & 0.8 & 0.7 \\
\hline $\begin{array}{l}\text { Education, in total } \\
\text { RUB bln }\end{array}$ & 836 & 888 & 928 & 887 \\
\hline $\begin{array}{l}\text { HE } \\
\text { (in \% as to GDP) }\end{array}$ & $\mathbf{0 . 6}$ & 0.5 & 0.5 & 0.5 \\
\hline HE (RUB bln) & 615 & 599 & 629 & 643 \\
\hline
\end{tabular}

Source: compiled by the authors on the basis of the current legislation

With respect to the GDP of the relevant year, the share of expenses in the Education section is $0.8 \%$ in $2019-2021$, and $0.7 \%$ in 2022. According to the experts from the Russian Academy of National Economy and Public Administration under the President of the Russian Federation and the Gaidar Institute for Economic Policy, "in order to solve the problems of the education sector in the near future, $0.8 \%$ of GDP spent from the federal budget on education are the required minimum". Researchers from the Higher School of Economics also note that HE as "a system can function under insufficient financial support, but only in an inertial manner. When trying to get it out of this state, the system becomes unbalanced, and the effects of underfunding strengthen" (Kosov et al., 2017).

As per the experts from the Chamber of Commerce and Industry of the Russian Federation, "according to the world experience, sustainable development of the economy is possible when at least $5-7 \%$ of GDP are spent on education" (Morozova et al., 2020).

This scientific and educational community has been following this position since the early 2000s. It was taken into account in 2008 when developing the Concept for Long-Term SocioEconomic Development of the Russian Federation until 2020, which provided that private and public expenses on education should amount to $6.5-7 \%$ of GDP by the late 2020 (Kosov et al., 2018).

However, these indicators have not yet been achieved. Thus, the problem of full-fledged financing of education should be solved in the next decade. Therefore, in accordance with the Forecast of Long-Term Socio-Economic Development of Russia for the Period up to 2030, developed by the Ministry of Economic Development of Russia, in 2030, the expenses on education should be brought to $6.0-6.5 \%$ of GDP.

In the authors' opinion, only this volume of financial resources will allow HE to efficiently fulfill its main function on developing the human capital (Kosov et al., 2019).

The principle of diversified (or multichannel) financing, whose expediency was scientifically substantiated back in the 1990s, is used when forming the resource base of state programs and national projects. Thus, the Education national project and ten federal programs included in it assume the total funding in the amount of RUB 784.5 bln from all sources (Fig. 3). 
Figure (3): Multichannel Financing of National and Federal Projects, RUB bln ${ }^{1}$

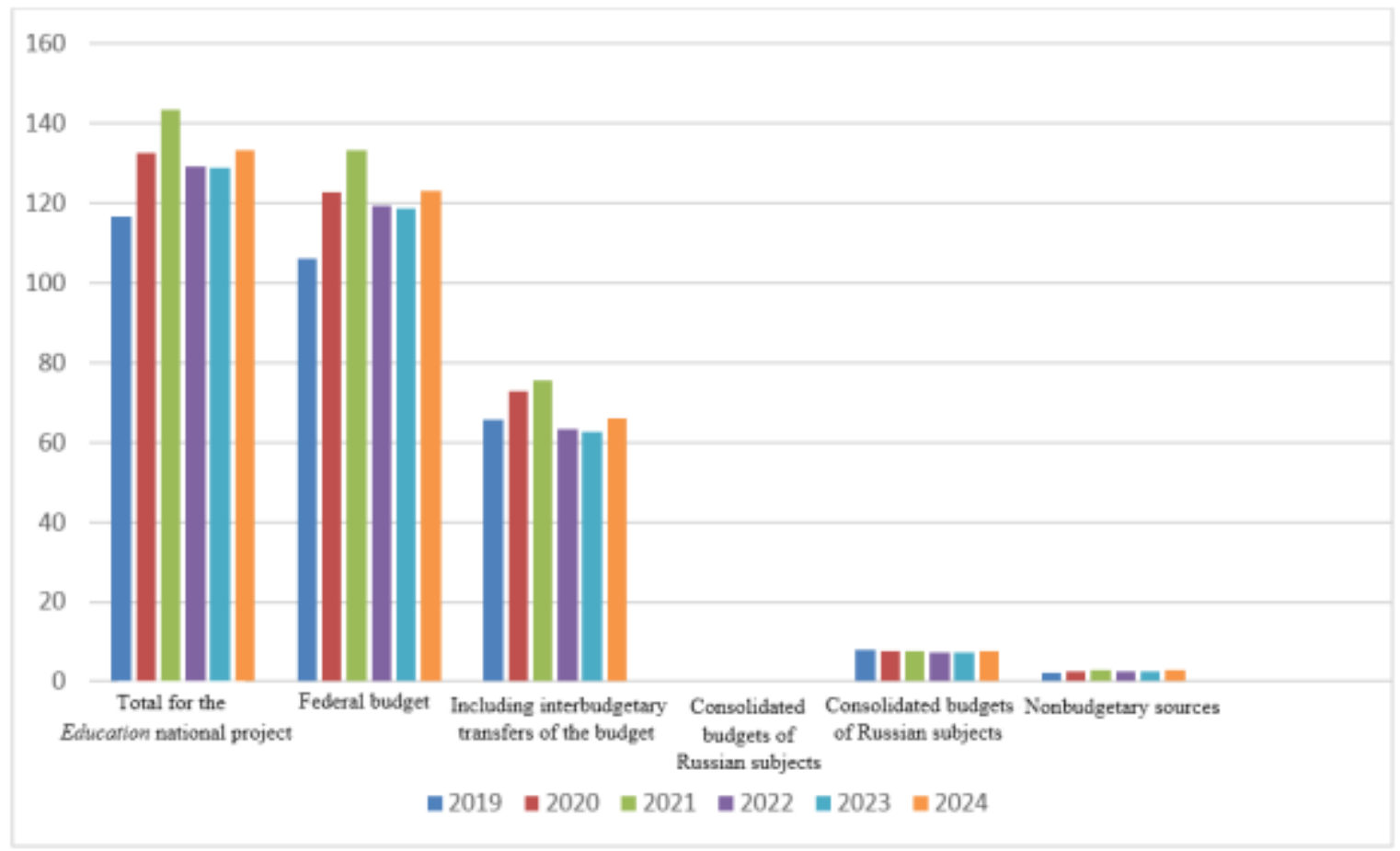

Source: compiled by the authors according to the passport of the Education national project

In the structure of financing the Education national project, the largest share of the federal budget is $92 \%$, the share of consolidated budgets of the Russian Federation subjects is about $6 \%$, and nonbudgetary sources account for $2 \%$. Thus, national projects are based on the principle of diversified financing, but it does not guarantee sufficiency of financial resources for the HE development if it is not supported by the relevant investments both from the state and private investors (Kosov et al., 2020).

The principle of priority means the focus of financial resources on achieving goals and objectives determined by the relevant decrees of the President of the Russian Federation. This principle is most fully implemented in the project approach to financing HE.

In the authors' opinion, such federal projects as Young Professionals that improves the competitiveness of professional education (RUB 156.2 bln), Export of Education (RUB 107.5 bln) that contributes to the development of the export potential of the Russian HE, Digital Educational Environment that gradually forms the digital educational environment (RUB 77.4 bln), and New Opportunities for Everyone that stimulates the development of additional and continuing professional education (RUB 9.2 bln) are the most important for HE.

The principle of the performance of investments in scientific and educational activities of HEls and human development is one of the most important principles for improving the investment attractiveness of HE. According to the authors, "the rate and performance of the national HE are determined by the efficiency of interaction among the society, its citizens, government and commercial structures, nongovernment funds, and private investors, which is expressed in the legislatively determined level of financing $\mathrm{HE}^{\prime \prime}$.

The world experience shows that all countries with developed economies provide education with government support. For example, in Finland, Sweden, Ireland, Germany, Japan, and other countries that have the best education systems according to the Global Index of Cognitive Skills and Educational Attainment, the state's share in financing education is over $70 \%$. "On average in the OECD, the state's share in financing nontertiary (higher) education is $90 \%$. The relevant indicators

1 Passport of the Education national project (approved by the General Committee under the President of the Russian federation on Strategic development and National Programs, Minutes No. 16 dated 24.12.2018) 
that are above this average level are found in Austria (95\%), Belgium (97\%), the Czech Republic (92 $\%)$, Estonia (93\%), Finland (99\%), Norway (99\%), Iceland (96\%), and a number of other countries, as well as in the Russian Federation (95\%)".

It means that in Russia the main investor in the development of human capital is the state. Accordingly, certain results of the HEls' operation are measured by quantitative and qualitative indicators approved by the Ministry of Science and Higher Education of the Russian Federation, and taken into account when allocating financial resources (Dorofeyev et al., 2018). In particular, according to the Ministry, "in 2020, $60 \mathrm{HEls,} \mathrm{which} \mathrm{in} \mathrm{the} \mathrm{course} \mathrm{of} \mathrm{inspecting} \mathrm{the} \mathrm{performance} \mathrm{had}$ been assessed as poor, were not financed for fundamental research. Thirty-two HEls were recognized as leading. Ninety-six ones were placed in the second category, and 64 - in the third one". However, due to the transition to diversified funding, the HEls of the third category can obtain grants or subsidies on a competitive basis (Koh et al., 2014).

It is quite difficult to measure the performance of the transformation of investments in the results of HEls' scientific and educational activities. As a rule, such assessment is carried out by calculating the internal rate of return on investment, the net present value, and the payback period of the investment. In the world practice, the following indicators are used to assess the feasibility of investing in education projects: "coefficient of social profitability, indicator of net present social value, the index of social profitability, and coefficient of the internal rate of social profitability" (Policy Nonprofit Public. A Sourcebook on Think Tanks in Government, 1993).

According to the authors, in order to assess the performance of investing in the research and educational activities of HEls and the human potential development, it is necessary to introduce index of the investment attractiveness of HEls, taking into account the human development indices in relation to teachers and students. In this case, the assessment aims at comparing the investment attractiveness of various HEls' groups based on the integral indicators. In the authors' opinion, the system of integral indicators of the HEls' investment attractiveness should include the following:

$>$ The index of competitiveness (attractiveness) of educational programs (Kop) determined on the basis of the following ratings: QS WUR world ranking, the global ranking of the HEls' impact on achieving the UN sustainable development goals (The Impact Rankings), the rating of the SuperJob portal according to the Salary of Graduates of Economic Universities, RAEX and Interfax national ratings (Cipriano, Riccardi: 2016),

$>$ The index of the HEl's performance as objectively assessed by the Ministry of Education and Science of the Russian Federation, including the employment of HEl's graduates ( $\mathbf{R r}$ ) - according to the HEl's performance as monitored by the Ministry of Education and Science of the Russian Federation or/and other similar ratings,

$>$ The index of the general efficiency of the HEl's Development Program (Fo) determined by the experts from the Ministry of Education and Science of the Russian Federation,

$>$ The financial management quality index $(\mathbf{K f m})$ determined on the basis of the results of the Financial Management Quality Monitoring carried out by the Ministry of Education and Science of the Russian Federation. For example, it is possible to use "the information and analytical portal for monitoring the quality of financial management and the performance of Russian HEIs of the Ministry of Education and Science of Russia as part of the unified information system of the Government of the Russian Federation as the basis for the electronic interaction" (Koshy et al.: 2016),

> The human development index for academic staff and HEl's staff, (Ios), taking into account the average age, average wages, the average level of graduation of the teaching staff and employees that can be calculated by using the formula as the geometric mean of three private indices:

$$
I_{o s}=\sqrt[n]{I_{1} * I_{2} * I_{n}}
$$


> The human development index (in relation to students of HEI) (Iss) that takes into account the health, education (bachelor's, specialist's, master's, postgraduate degrees) and the remuneration of the HEl's graduate/student. It can also be determined by using the formula as the geometric mean of three partial indices,

$>$ The index of the information and educational environment quality (Kios) that takes into account the availability of a digital campus, the number of massive open online courses (MOOCs) on global and national educational platforms, the quality of the digital learning environment, the business process automation, the availability of a system of network interactions with leading Russian and foreign universities, scientific organizations, enterprises, investors, innovation support centers, etc.

$>$ The index of the project financing performance (Rpf), taking into account the integration of the results of financing certain projects, including the assessment of the HEl's participation in national projects (first of all, in the Science, Education, and Demography projects and the Digital Economy of the Russian Federation national program of a HEI within Monitoring the Development of HE Institutions 2.0).

It is necessary to calculate the multi-integral indicator of the investment attractiveness of a HEl combining the above indicators as a weighted arithmetic mean by using the formula:

$$
a=\frac{\sum\left(I_{n} * x_{i}\right)}{\sum x_{i}}
$$

where $\boldsymbol{a}$ is the multi-integral index of the HEl's investment attractiveness, $\boldsymbol{I} \boldsymbol{n}$ is the integral index included in the system for assessing the HEl's investment attractiveness, and $\boldsymbol{x} \boldsymbol{i}$ is the weighted value of the integral index determined in the expert manner.

The weighted values of the integral indices included in the calculation and their ranking according to the importance for the HEl's investment attractiveness are determined by the experts of the Ministry of Education and Science of the Russian Federation. The assessment model will be the ratio of the value of the multi-integral index of a particular HEl's investment attractiveness to the value of the investment attractiveness index of the best HEl in the group (Policy Nonprofit Public. A Sourcebook on Think Tanks in Government, 1993).

The principle of optimal distribution of risks among investors of subjects in the HE area can be fully implemented if the share of attracted nonbudgetary funding sources is at least $5 \%$. However, even with the current share ( $2 \%$ of nonbudgetary investments in the Education national project), there are considerable risks in implementing the project approach to financing HEls in the context of the economy and education digitalization.

In the authors' opinion, the greatest probability of risks occurs when implementing the Digital Educational Environment federal project aimed at achieving key indicators of the Education Digital Infrastructure, and Digital Economy national projects.

These include:

- Social risks in $\mathrm{HE}$, i.e., possible negative consequences of digitalizing $\mathrm{HE}$ as a social institution, substantiated by the difficulties of the transition to digital technologies in HEls and problems of the practical use of digital technologies in the HE. The widespread use of not only distance learning, but also virtual and alternate reality and digital alter ego technologies increases the risks of virtual addiction and loss of creative potential by students. In the future it may decrease the quality of human capital,

- General economic risks caused by a sharp decrease in GDP, revenues of the federal and regional budget, the growth of inflation, the decrease in the purchasing power of the population due to COVID-19, etc. Hence, there are risks of underfunding of federal programs included in national projects, 
- Regulatory and legal risks, including the untimely adoption of regulatory legal acts, as well as amendments to the current budget and tax legislation that have impact on financing and the investment attractiveness of the HE sector, including minimizing negative consequences of its digitalization,

- Organizational and management risks determined by the professional competence of leaders of the sector and educational organizations, as well as the efficiency of the organizational and managerial structures of HEls, and

- Risks of loss of financial stability by HEls, including due to the situation with the coronavirus. Thus, for example, according to the Ministry of Science and Education of the Russian Federation, "in 2020 about 70 - 80 out of 252 Russian HEls have extremely high risks of losing their financial stability". Due to this, the President of the Russian Federation "agreed with the suggestion to empower regions, subject to the availability of resources, to directly finance programs for the development of local HEls and their infrastructure, regardless of their subordination".

The authors believe that in order to minimize the above risks, it is necessary to expand the methodological basis of project financing of HE by introducing the value-based approach to it as a specific way of organizing and implementing the management and financial and economic activities of HEls, obtaining and using its results with regard to certain values (Fig. 4).

Figure (4): Value-Based Approach to Project Financing of HE

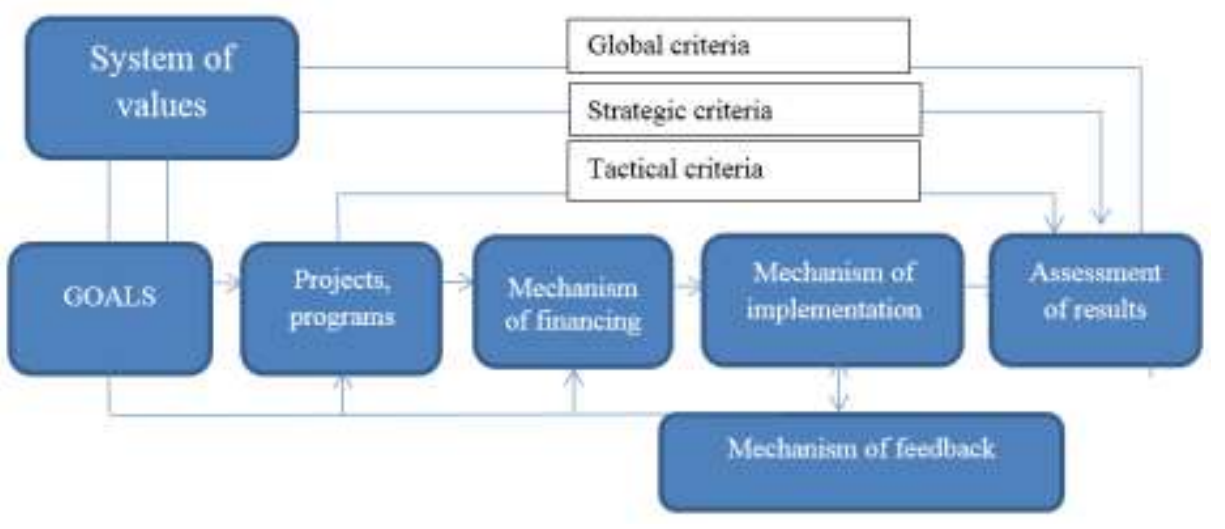

The authors believe that in order to improve the development of human potential that determines the quality of human capital, in HE the value system should be formed within the valuebased (axiological) approach rather than within the competence-based approach to learning. The latter considers a person both as the highest goal and value of the society, and the self-goal of the social, personal, and professional growth (Bykanova et al., 2017). This gives rise to global, strategic, and tactical criteria for assessing the results of implementing national projects and state programs in education. At the same time, the choice of financing technologies and implementing projects should correspond to the set targets, and the feedback mechanism should provide reliable information confirming their achievement (Slepov et al., 2019). The value-based approach to project financing of HE will help minimizing the risks of implementing the Education national project and its basic component - the Digital Educational Environment federal project.

Firstly, social risks of digitalizing education are neutralized, because this approach implements the axiological focus of the HE development as a social institution, and is based on the value-based core that determines the goals and priorities of the educational process. The main one is to create conditions for an independent and conscious choice of a behavior strategy and a trajectory of learning, self-realization and self-development by each student in the context of universal and traditional values, and, as a consequence, the formation of a personality with high professional potential and communicative culture required for the successful socialization in the 
society, including through the introduction of adaptive, practice-focused and flexible educational programs (Gibson, 2017).

Secondly, general economic risks and risks of state underfunding of projects in the area of education are compensated by improving the investment attractiveness of HE for private investors and development institutions. The value-based approach grounded on the early self-determination and self-development of a pupil/student contributes to

- Improving the quality of education by increasing the percentage of people employed in their specialty (Kosov et al., 2018),

- Introducing the "system for monitoring the employment of graduates, taking into account the satisfaction of employers with the quality of graduates training in the context of HEls and their educational programs (Kosov et al., 2016), and

- Complying of the training areas with regional labor markets and the sectoral structure of the economy, taking into account the self-employment sector" (Kosfeld et al., 2011), including due to the methodologically correctly used target model of the digital educational environment that creates profiles of "digital competencies" for educators and learners that allow designing and implementing individual curricula (programs) and assessing the quality of education (Armstrong et al., 2017).

Thirdly, the value-based approach makes it possible to prevent regulatory and legal risks. For example, using the created federal information and service platform of the digital educational environment that has a set of standard information solutions, including for the implementation and correction of regulatory legal acts, it is possible to strategically correctly focus these solutions relying on the set goals and priorities of the education development with regard to its strategic goals (Fusch, Ness, 2015; Cook-Sather, 2006).

Fourthly, organizational and management, financial risks are minimized due to the introduction of value-based management (including financial) as methodologically substantiated and based on humanistic psychology and a personality-based approach of the management technology that implements the tasks of a unified health-saving pedagogical system, which is especially relevant in the context of COVID-19. The authors believe that such approach to organizing and assessing the results of the Center for the Digital Transformation of Education that will perform organizational and management, methodological, analytical and expert activities aimed at ensuring high quality and accessibility of education of all types and levels, as well as training management teams of HE subjects will be able to provide an integrated approach and the efficiency of strategic and operational financial decisions (Geuna, Piolatto, 2016; Kohavi et al., 2009).

Fifthly, the risks of losing financial stability by HEls are reduced, because the value-based principles of financial resource management include the rules that determine and regulate the current financial activities and principles that clarify the financial strategy and target orientation of the HEIs' development that make it possible to efficiently use the creative potential of all HEI's employees.

The main advantage of the value-based approach is that it does not require any additional investments in the development of human capital, in addition to those provided for by the Education national project. At the same time, the index of investment attractiveness of HEls is improved, including the indices of human development of the teaching staff, employees, and students.

\section{CONCLUSION}

The forecasted negative consequences of global and local challenges, as well as possible risks of digitalizing the educational environment of HEls require adjusting and developing the methodology of project financing in HE. The optimal combination of methodological approaches to the financial support of national projects in education allows the state to fulfill social obligations, on 
the one hand, and to stimulate the development of the HE system, on the other hand, considering it as the investment area that forms the knowledge economy. According to the authors of the study, expanding the methodological basis for project financing of HE by introducing the value-based approach to it improves the index of the investment attractiveness of Russian HEls and neutralizes the risks of the HE digitalization. Along with this, the value-based approach to project financing of HEls contributes to the formation of a flexible educational ecosystem in this area of Russian education within national projects. This ecosystem is focused on traditional cultural and moral values, unites objects and subjects of financial support and investments, including users and providers of educational services, and develops the human potential.

Authors' Contributions: Vladimir Alexandrovich Slepov: designed the study, prepared the plan, wrote the first draft of the manuscript and edited the final version. Atyana Nikolaevna Rodenkova: designed the study, prepared the plan, wrote the first draft of the manuscript and edited the final version. Elena Ivanovna Gromova: designed the study, prepared the plan, wrote the first draft of the manuscript and edited the final version. Dmitry Alexandrovich Pokamestov: designed the study, prepared the plan, wrote the first draft of the manuscript and edited the final version. All authors read and approved the final manuscript.

Ethics Approval: Not applicable.

Acknowledgments: Not applicable.

\section{REFERENCES}

Abramo, G., Cicero, T., D’angelo, C.A. (2013). Individual research performance: A proposal for comparing apples to oranges. Journal of Informetrics, 7(2), 528-539.

Agasisti, T., Munda, G., Hippe, R. (2019). Measuring the efficiency of European education systems by combining Data Envelopment Analysis and Multiple-Criteria Evaluation. Journal of Productivity Analysis, 51(2-3), 105-124.

Armstrong, D.E., Woloshyn, V.E. (2017). Exploring the Tensions and Ambiguities of University Department Chairs. Canadian Journal of Higher Education, 47(1), 97-113.

Ben-Ner, A., Siemsen, E. (2017). Decentralization and Localization of Production. California Management Review, 59(2), 5-23.

Bykanova, O.A., Akhmadeev, R.G., Kosov, M.E., Ponkratov, V.V., Osipov, V.S., Ragulina, Y.V. (2017). Assessment of the economic potential of sovereign wealth funds. Journal of Applied Economic Sciences, 12(1), 70-84.

Camargo, E. D. F., \& Givigi, R. C. N. (2021). The relationship between the school organization and the process of inclusion of an autistic student. Journal of Research and Knowledge Spreading, 2(1), e12354.

Cipriano, R.E., Riccardi, R.L. (2016). The department chair: a nine-year study. The Department Chair, 27(1), 16-18.

Cook-Sather, A. (2006). Newly Betwixt and Between: Revising Liminality in the Context of a Teacher Preparation Program. Anthropology and Education Quarterly, 37(2), 110-27.

Coviello, D., Guglielmo, A., Spagnolo, G. (2018). The Effect of Discretion on Procurement Performance. Management Science, 64(2), 715-738.

Crespi, G.A., Geuna, A. (2008). An empirical study of scientific production: A cross country analysis, 1981-2002. Research Policy, 37(4), 565-579.

Dorofeyev, M., Kosov, M., Ponkratov, V., Masterov, A., Karaev, A., Vasyunina, M. (2018). Trends and Prospects for the Development of Blockchain and Cryptocurrencies in the Digital Economy. European Research Studies Journal, XXI(3), 429-445.

Fusch, P.I., Ness, L.R. (2015). Are we there yet? Data saturation in qualitative research. The Qualitative Report, 20(9), 1408-1416.

Geuna, A., Piolatto, M. (2016). Research assessment in the UK and Italy: Costly and difficult, but probably worth it (at least for a while). Research Policy, 45(1), 260-271.

Gibson, I. (2017). The changing face of additive manufacturing. Journal of Manufacturing Technology Management, 28(1), 10-17. 
Koh, A.C., Gammoh, B.S., Okoroafo, S.C. (2014). An Investigation of Export Practices and Performance across Global Mindset Orientations. International Business Research, 7(1), 60-73.

Kohavi, R., Longbotham, R., Sommerfield, D., Henne, R.M. (2009). Controlled experiments on the web: survey and practical guide. Data Mining and Knowledge Discovery, 18(1), 140-181.

Kosfeld, R., Eckey, H.-F., Lauridsen, J. (2011). Spatial point pattern analysis and industry concentration. The Annals of Regional Science, 47(2), 311-328.

Koshy, P., Seymour, R., Dockery, M. (2016). Are there institutional differences in the earnings of Australian higher education graduates? Economic Analysis and Policy, 51, 1-11.

Kosov, M.E., Akhmadeev, R.G., Osipov, V.S, Kharakoz, Yu.K., Smotritskaya, I.I. (2016). Socio-Economic Planning of the Economy. Indian Journal of Science and Technology, 9(36), 102008.

Kosov, M.E., Akhmadeev, R.G., Smirnov, D.A., Solyannikova, S.P., Rycova, I.N. (2018). Energy industry: Effectiveness from innovations. International Journal of Energy Economics and Policy, 8(4), 83-89.

Kosov, M.E., Akhmadeev, R.G., Smirnov, V.M., Popkov, S.Y., Rycova, I.N. (2017). Hydrocarbon market in countries with developing economy: Development scenario. International Journal of Energy Economics and Policy, 7(6), $128-135$.

Kosov, M.E., Sigarev, A.V., Malashenko, G.T., Kharakoz, J.K., Sekacheva, A.B. (2019). Economic cycles: Influence on the innovation system of Russia. Journal of Advanced Research in Law and Economics, 10(6), 1794-1800.

Kosov, M.E., Sigarev, A.V., Sharov, V.F., Makashina, O.V., Smirnov, V.M. (2020). Sovereign wealth funds: Russian and international experience. Space and Culture, India, 7(4), 246-254.

Kumar, C.S., Turvey, C.G., Kropp, J.D. (2013). The Impact of Credit Constraints on Farm Households: Survey Results from India and China. Applied Economic Perspectives and Policy, 35(3), 508-527.

Morozova, T., Akhmadeev, R., Lehoux, L., Yumashev, A., Meshkova, G., Lukiyanova, M. (2020). Crypto asset assessment models in financial reporting content typologies. Journal of Entrepreneurship and Sustainability Issues, 7(3), 2196-2212.

Policy Nonprofit Public. A Sourcebook on Think Tanks in Government. (1993). New York, London.

Ramos-Vielba, I., Sánchez-Barrioluengo, M., Woolley, R. (2016). Scientific research groups' cooperation with firms and government agencies: motivations and barriers. The Journal of Technology Transfer, 41(3), 558-585.

Rodenkova, T.N. (2011). Methodological foundations of financial support for innovative development of higher education. Moscow: PRUE im. G.V. Plekhanov.

Sabharwal, M. (2013). Productivity and Leadership Patterns of Female Faculty Members in Public Administration. Journal of Public Affairs Education, 19(1), 73-96.

Souza, F. M. A., \& Ferreira, L. G. (2021). Contemporary Teacher education: contributions and learning. Journal of Research and Knowledge Spreading, 2(1), e11914.

Slepov, V.A., Rodenkova, T.N., Kosov, M.E., Grishin, A.I. (2019). Human Capital Development as an Element of Financial Management in National Education Systems. Journal of Advanced Research in Law and Economics, 4(42), 1303-1308.

Received: 2 May 2021 | Accepted: 10 June 2021 | Published: 23 June 2021 